\title{
A Conceptual Model of Sales Tax Compliance among Jordanian SMEs and Its Implications for Future Research
}

\author{
Ahmad Farhan Alshira'h ${ }^{1} \&$ Hijattulah Abdul-Jabbar ${ }^{2}$ \\ ${ }^{1}$ Faculty of Finance and Business Administration, Al al-Bayt University, Jordan \\ 2 Tunku Puteri Intan Safinaz School of Accountancy, Universiti Utara Malaysia, Malaysia \\ Correspondence: Ahmad Farhan Alshira'h, Department of Accounting, Al al-Bayt University, Jordan. Tel: \\ 962-795-103-520. E-mail: Alshraah.ahmad@yahoo.com
}

Received: February 16, 2019

Accepted: March 13, 2019

Online Published: April 25, 2019

doi:10.5539/ijef.v11n5p114

URL: https://doi.org/10.5539/ijef.v11n5p114

\begin{abstract}
Tax compliance is a serious and growing issue all over the world. The government of Jordan undertakes various fiscal measures to maximize domestic throughout the past few decades but according to the annual reports, the country still faces a sharp increase in net public debt and fiscal deficit brought about by the increase in the rate of tax non-compliance, and this particularly holds true for sales tax. Therefore, this study generally focuses on the topic of tax non-compliance, specifically sales tax in the Jordanian context. Literature is still lacking of studies that examined determinants of sales tax compliance and several determinants may be the causes behind the non-compliance phenomenon but a general tax compliance model is not effective in explaining the issue. Therefore, for an in-depth understanding of sales tax compliance determinants in Jordanian SMEs, the present research brings forth an extension of Fischer's model of tax compliance, with the addition of the moderating influence of tax services quality. The proposed model takes social, psychological and economic factors into consideration within one comprehensive model to provide insight into sales tax compliance among SMEs in Jordan.
\end{abstract}

Keywords: sales tax compliance, Fischer model, tax services quality

\section{Introduction}

\subsection{Introduce the Problem}

A country's development and growth is generally dependent on the revenue level obtained (Samuel \& Dieu, 2014), and in this regard, taxes form one of the top major national revenue sources all over the globe (Alshir'ah, Abdul-Jabbar, \& Samsudin, 2016; Varvarigos, 2016). Because governments are in constant need of funds to invest in public infrastructure, health services, education and public services, there is a need to increase tax revenue if development and growth are to be boosted (Bird, Martinez-Vazquez, \& Torgler, 2008). Throughout the years, the tax authority has been facing challenges, especially following the 2008 world economic crisis. The fiscal deficit has led to the considerable increase in the need for tax revenue and the government has turned towards collaborating with other governments in order to solve the non-compliance issue (Sawyer, 2014). The tax revenue can be increased only when efforts are exerted towards encouraging tax compliance (Franzoni, 1999). tax compliance increase will logically increase the tax revenue. In fact, non-tax compliance is permeating concern all over the globe in both developing and developed nations (Alm, Clark, \& Leibel, 2016; Feinstein, 1991). And Middle Eastern countries are not exception (Al-Ttaffi \& Abdul-Jabbar, 2015). Thus, tax compliance issue remains a ripe area to examine in research. Although several studies have been dedicated to the issue, no consensus has been reached as to the drivers of tax payment compliance (Randlane, 2016). So long as there is taxation, the problem of tax non-compliance is predicted to persist.

Sales tax has transformed into one of the top proportion of tax revenue all over the world and it has a tendency to be the main point of interest in tax policy decision-making, specifically in developing nations. Sales tax, also known as value-added tax (VAT) in the UK, the U.S. and France is known as goods and services tax (GST) in Australia, Singapore and Malaysia. The first introduction of VAT was in 1954 in France (Adams \& Webley, 2001). In the current times, it has permeated approximately 160 countries where it is applied (Azmi, Sapiei, Mustapha, \& Abdullah, 2016). This is because of its high effective means of obtaining tax revenue that generates 
a significant amount while reducing deficits (Lee, Kim, \& Borcherding, 2013), and this holds true in developing nations (Faridy, Freudenberg, Sarker, \& Copp, 2016). In the present day, sales tax has become tax revenue that shapes the consumption tax system applied in several nations (Giesecke \& Tran, 2012). However, the sales tax compliance issue all over the globe remains a thorn on the side of policy makers of all the countries, particularly those with developing economies (Das-Gupta \& Gang, 2003). Owing to its responsibility nature, sales tax compliance reflects a high burden on SMEs in comparison to other taxes types (Hansford \& Hasseldine, 2012).

In the context of Jordan, the country highly depends on tax revenue, a crucial element in the public budget, constituting approximately 70\% towards the domestic revenue for the period 2010 to 2016 (Ministry of Finance [MOF], 2016). Issues of tax compliance have in fact become a national issue as it influences the economy of Jordan (Al-Shawawreh \& AL-Smirat, 2016). Although the government has adopted various fiscal measures to increase domestic revenue (development of national economy, financial stability), based on the annual reports of businesses, Jordan is still faced with an increase in net public debt, amounting to JD27, 520 billion (MOF, 2016). Moreover, with the exclusion of grants and international assistance, the country's fiscal deficit has worsened with the increase in non-compliance of tax payment from JD1.447 billion (2010) to JD1.720 billion (2016) (MOF, 2016). Correspondingly, the tax non-compliance estimates have also shown a sharp rise by 48\%, with sales tax non-compliance constituting 71\% of the total non-compliance for the period 2011 to 2015 (see figure 1) (Jordan Independent Economic Watch, 2014). It is evident from the above that tax non-compliance, particularly sales tax requires focus in Jordan, considering the fact that it is compounded by the limited economic resources of the country, as a result of which it suffers from chronic fiscal deficit, necessitating an injection of funding to meet the development requirements of the economy and society (Al-Zoubi, Khatatba, Salama, \& Khatataba, 2013). In other words, tax compliance is a must among taxpayers due to the outcomes for the government revenue, financial stability of the country and the capacity to react to the needs of the community.

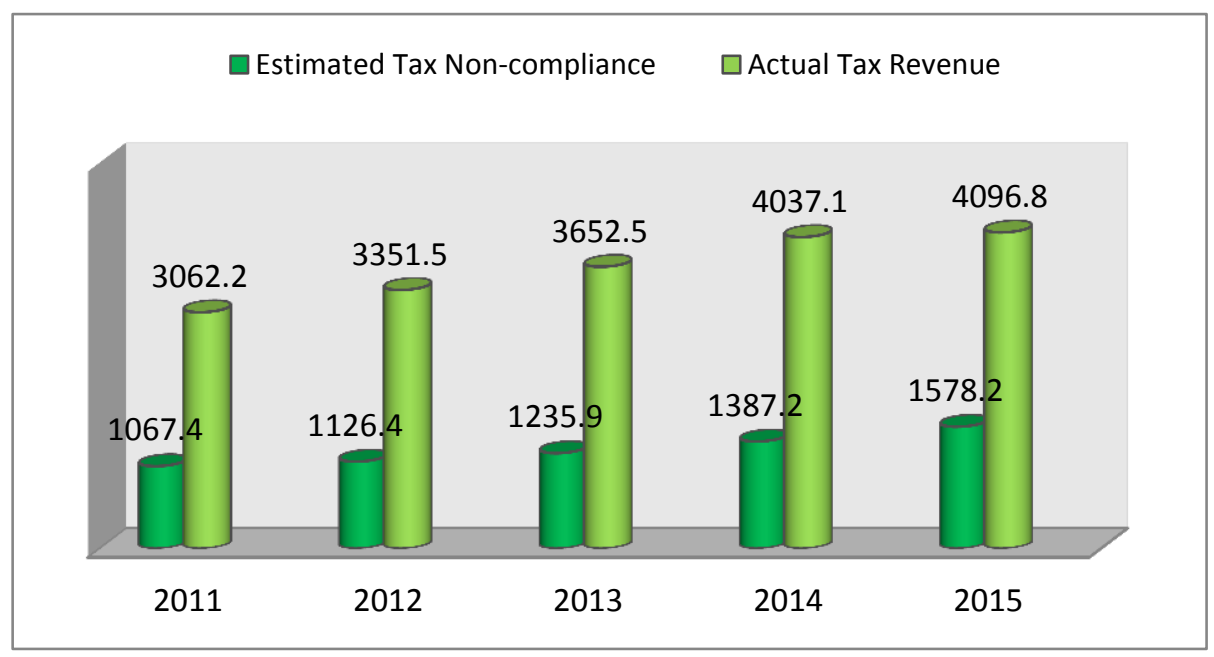

Figure 1. Tax non-compliance and tax revenue in Jordan from 2011-2015

In the Jordanian business community, SMEs have a major role, constituting over $99 \%$ of the businesses in the national economy (Lutfi, Idris \& Mohamad, 2017; Association of Banks in Jordan, 2016), and contributing approximately $50 \%$ of the GDP, while employing $60 \%$ of the total workforce, and possessing the capability of raising exports, providing foreign currency and mitigating the payment deficit equilibrium, and providing larger companies with services goods and materials (Alrousan \& Jones, 2016; Saymeh \& Sabha, 2014). In this regard, SMEs are perceived as the major contributors to the Jordanian shadow economy, contributing around $90 \%$ to it (United Nations Development Programme, 2012). In terms of sales tax non-compliance, 87\% of small enterprises and $34 \%$ of their medium counterparts have been reported to have failed sales tax payment (Young Entrepreneure Association, 2011). Added to this, SMEs often fail to keep good accounting records, with a mere $14 \%$ of them revealed to have a prepared accounting information, $40 \%$ inclined towards including important items in when reporting their financial progress (Al-Bakri, Matar \& Nour, 2014; Al-Smirat, 2013). Therefore, business tax compliance is crucial to the fiscal of governments (Joulfaian, 2009). This is especially true since the bulk of the country's tax revenues are paid or collected by business (Joulfaian, 2000).

Prior theoretical studies have revealed several drivers of tax compliance behavior (Alm \& Torgler, 2011). 
Throughout history, the economic approach posits that deterrence has been the strategy for tax compliance enforcement (Frey, 2003). The pioneering economic studies dedicated to tax non-compliance were based on Becker's Model (1968) of economics-of-crime proposed to resolve illegal actions. In this regard, the deterrence policy has its basis on the premise that threats through legal penalties will facilitate crime prevention (Matthews \& Agnew, 2008). In particularly, Becker (1968) explained that if the taxpayers are rational in their behavior, then each and every one of them will maximize the expected use of the tax non-compliance gamble by determining the benefits from successful tax non-compliance against those of penalty and tax audit. In the same line of study, Allingham and Sandmo (1972) were the first authors to use the deterrence theory based on Becker's model to propose a tax non-compliance theory known as the A-S model. The A-S model is deemed to be the most pioneering model that addressed the resolution of tax non-compliance. Despite this fact, the deterrence theory has been, time and again, criticized by several researchers. To begin with, Feld, Frey and Torgler (2006) revealed that in the face of low deterrence level, the tax compliance level is high in some countries and thus, the model does not completely explain the tax compliance behavior. Thus, there may be other factors that drive tax compliance that are not covered in the deterrence theory. Similarly, Jackson and Milliron (1986) highlighted the weakness of the deterrence theory in explaining tax compliance behavior and provided 14 factors influencing non-compliance, which were divided into four groups. The four groups consist of tax system comprising of tax complexity, tax audit, tax penalty and tax rates, attitude and perception comprising of tax moral, tax fairness and peer influence, demographic characteristics comprising of age, gender and education, and lastly, non-compliance opportunity comprising of income level, occupation and income source. The above factors were organized by Fischer, Wartick and Mark (1992) into one model that is built on the combination of socio-psychological and economic approaches, which later became known as the Fischer model. This model garnered support from several studies including Kirchler (2007) and Andreoni, Erard and Feinstein (1998).

Therefore, this study is an attempt to contribute to literature in the following ways; first, prior studies have examined the drivers of tax compliance using extended Fischer model through the addition of relevant factors (e.g., Chau \& Leung, 2009; Chan, Troutman, \& Bryan, 2000; Hanefah, 1996). Such extensions, with both economic and socio-psychological factors, did not involve the incorporation of tax services quality moderating the relationship between the variable and sales tax compliance among SMEs in Jordan. These variables should not be overlooked when shedding light into sales tax compliance, particularly in the Jordanian context. Second, this research determines sales tax compliance in the business context with the help of Fischer's model (1992), involving owners/managers of SMEs in Jordan. The Fischer model is thus utilized in this study in the business context level rather than in the individual's context. According to Abdixhiku, Krasniqi, Pugh, and Hashi (2017), the determinants of tax non-compliance have yet to be extensively examined in the literature dedicated to tax. Abdixhiku, Pugh and Hashi (2018) indicated that the lack of studies on tax non-compliance by businesses is unfortunate, particularly given the fact that in most countries the majority of taxes is paid by business and business account for the size of tax non-compliance too (Nur-tegin, 2008; Crocker \& Slemrod, 2005). Moreover, SMEs have ample opportunities to steer clear of non-paying taxes compared to individuals as evidenced by Woodward and Tan (2015). Also, there appears to be a significant focus on individual tax compliance with business tax compliance largely overlooked and this as claimed by Alm and Mc Clellan (2012). Furthermore, in order to be consistent with sales tax compliance among SMEs, some Fischer model features are excluded (non-compliance opportunity and demographic features).

Third, this study is expected to determine the effect of the deterrence theory on sales tax compliance, whereas majority of studies in literature have tackled the relationship between the deterrence theory and compliance to income tax, with only a few addressing sales tax compliance (e.g., Woodward \& Tan, 2015; Faridy, Copp, Freudenberg, \& Sarker, 2014; Webley, Adams, \& Elffers, 2004). To the best of the knowledge of the researcher, no study has been conducted to examine the effects of deterrence theory on sales tax compliance, particularly in the Middle Eastern countries, particularly Jordan. Fourth, the study determines the effects of socio-psychological factors on sales tax compliance. This is because despite the several studies dedicated to examining tax, majority of them made use of non-economic factors and their effect on income tax compliance, and they focused on individual level, with only a few studies addressing sales tax in business (e.g., Woodward \& Tan, 2015; Faridy et al., 2014; Webley et al., 2004). Similar studies have also been carried out in the developed nations' context with the Middle Eastern countries, particularly Jordan, largely left out. Fifth, this research confirms sales tax compliance drivers to mitigate the literature gap regarding the same. According to Alm and El-Ganainy (2013), studies dedicated to examining sales tax are still few and far between owing to its quick diffusion as a basic revenue tool for majority of countries' governments. Alshir'ah et al.'s (2016) review of tax studies in literature, indicates that there is a need to conduct studies on tax sales tax compliance, particularly in Jordan. Lastly, this is the first study to test the effect of tax services quality moderating role in the relationship between sales tax 
compliance and its determinants. Prior literature has primarily considered tax services quality as an independent variable in their examination and they were focused on its relationship with income tax compliance (e.g. Hughes \& Moizer, 2015; Vigoda-Gadot, 2006). To date, no study has tested the moderating role of tax services quality on the sales tax compliance and its determinants among SMEs.

With regards to the remainder of this study, the sections are organized in the following way; Section 2 contains the tax compliance definition and Section 3 presents tax compliance determinants. Section 3 presents the moderating role of tax services quality. Section 4 research method. Section 5 implications. Lastly, Section 6 contains the conclusion of the study.

\subsection{Sales Tax Compliance}

In developed and developing nations, taxes are deemed to be critical elements forming the total domestic revenue and on a global level, countries promotion of their economies largely depends on direct and indirect taxes (Tehulu \& Dinberu, 2014; Vadde, 2014). Moreover, compliance to tax payment is mandatory of all parties, regardless of whether they are corporate or individuals and all are expected to adhere to the tax law voluntarily unfortunately, some people refuse do so (Kirchler, Kogler, \& Muehlbacher, 2014). Tax compliance can be ensured by the taxpayers' participation in the decisions and expenditures of government (Alm, Jackson, \& McKee, 1993), and through the use of enhanced penalties coupled with tax audit (Alm \& Torgler; 2011). Notwithstanding the efforts exerted to promote tax compliance, the issue remains rife with complexity and it is still ever-present. No distinct standard and universal definition of tax compliance have been proposed in literature as highlighted by Devos (2008) but different authors provided different definitions. To begin with, tax compliance was defined by Andreoni et al (1998) as the inclination of the taxpayers to adhere to the tax laws to bring about the country's balanced economy. Similarly, tax compliance was referred to by Alm (1991) and Jackson and Milliron (1986) as the reporting of the entire incomes and payment of the entire taxes to meet the provisions of regulations, laws and court judgments. Meanwhile, compliance was defined by Roth and Scholz (1989) as the filing of the taxpayer of the entire required tax returns in a timely manner, with the returns containing accurate report tax liability based on the tax laws, regulations and court decisions applicable of the return being filed. In a recent definition of tax compliance, it was described as the act of the taxpayers in declaring all taxable income in an accurate manner, in filing tax returns, and in paying payable taxes within the established period (Alm et al., 1993). Moreover, tax compliance has also been compared to a game by Kirchler, Niemirowski and Wearing (2006) that depended on the reciprocal interactions between taxpayer decisions and tax authority, and trust of taxpayers in the law and fairness established by the tax system. In Brown and Mazur (2003), the authors revealed the multiple faceted measures of tax compliance, where the taxpayers' compliance are of three types namely, reporting compliance, filing compliance and payment compliance. More specifically, in the sales tax context, compliance is referred to as the adherence with the entire procedures and legislation, with the inclusion of actual and correct sales paid and collected reporting, actual sales liability, payment of the entire due taxes timely, and timely filing of tax returns (Nura, Abdul-Jabbar, \& Ibrahim, 2017). In this regard, tax non-compliance takes the form of tax evasion or tax avoidance - with the former related to illegal and intended businesses of institutions and individuals to minimize their legally due tax due, via underreporting of sales, income or wealth, over exaggeration of deductions, dispensations or loans, or by not filing tax returns accurately (Ritsatos, 2014; Alm, 2012). On the other hand, the latter (tax avoidance) refers to the tendency of the taxpayers to mitigate their taxes due via legal means (Slemrod, 2007). According to Kasipillai and Abdul-Jabbar (2006), tax non-compliance takes on different forms and it comprises failure to pay assessed taxes at its due date, overstatement of deductions, understatement of income and not submitting tax return within the established period or at all. Alshira'h, Abdul-Jabbar and Samsudin (2018) indicated that sales tax non-compliance is a widespread phenomenon that involves the process of manipulating sales tax invoice and altering tax reports to meet various targets, such as paying less sales tax, increasing earnings and reducing cost based on benefits accruing as a result of evading tax or depending on attitudes, beliefs and norms. Due to the very few studies examining the economic factors and socio psychological factors on sales tax, the current study is based on tax compliance literature that suited into sales tax context. The next section presents the determinants of sales tax compliance.

\subsection{Determinants of Sales Tax Compliance}

One of the top determinants of tax compliance behavior is tax complexity (Jackson \& Milliron, 1986). In this study, sales tax complexity is referred to as the actions related to the troubles facing businesses with sales tax law including frequent changes, excessive details, innumerable computations and details distinct records of businesses. A negative relationship was found by Cuccia and Carnes (2001) between tax complexity and the inclination or the capacity to adhere to tax payment and similarly, increased tax complexities and frequent 
amendment of different tax laws was evidenced by Abdul-Jabbar and Pope (2008) as having an inverse effect on SMEs performance. Also, Pope and Abdul-Jabbar (2008) indicated that tax complexity is often linked to tax compliance costs and thus, most businesses find it easier not to comply. Contrary to the above studies' findings, an insignificant relationship was found between tax compliance and tax complexity (Morse, Karlinsky, \& Bankman, 2009; Fauvelle-Aymar, 1999), but Yahaya (2015) evidenced a positive tax complexity-tax compliance linkage. In the context of sales tax, Biabani and Amezani (2011) revealed that tax complexity has no relationship with sales tax compliance. In contrast, other prior study found that tax complexity negatively influenced on sales tax compliance (Woodward \& Tan, 2015).

Another top determinant of sales tax compliance is tax audit and it safeguards tax compliance behavior (Jackson \& Milliron, 1986). Sales tax in this regard, is the tax authority's ability to promote businesses' payment of accurate sales tax amount and to guarantee that businesses do register for sales tax payment if their sales turnover equals to or is over the threshold registration. Prior studies generally evidenced a positive tax audit-tax compliance relationship (e.g., Feld \& Larsen, 2012; Alm \& Mckee, 2006; Pommerehne \& Weck-Hannemann 1996; Witte \& Woodbury, 1985). But a few studies reported no relationship between the same variables (Muche, 2014; Tehulu \& Dinberu, 2014), while other studies like Slemrod, Blumenthal and Christian (2001) and Palil, Zain and Faizal (2012) found a negative relationship between tax audit and compliance. In the sales tax context, not enough studies have been conducted to examine the tax audit role on sales tax compliance and what few studies exist showed positive influence of the former on the latter (Woodward \& Tan, 2015), while others found no relationship between the two variables (Faridy et al., 2014).

In addition to the above two determinants, tax rate is also considered in literature as one of the top determinants of tax compliance that forms the tax system structure (Richardson, 2006). Sales tax rate is defined in the present study as the percentage imposed on goods and services supplies, regardless whether they are imported from abroad or from free zones, and local producers if the supply is taxable by sales tax law. Prior studies showed a significant negative relationship between tax rate and tax compliance (Kim, 2008; Ali, Cecil, \& Knoblett, 2001), while some evidenced no significant relahip (e.g., Pellizzari \& Rizzi, 2014; Seren \& Panades, 2013). On a contrasting finding, Alm, Sanchez and Juan (1995) and Yitzhaki (1974) supported a positive relationship between increased rate of tax and increased tax compliance. With regards to sales tax compliance, the tax rate-sales tax compliance has not been extensively examined, with few studies dedicated to the relationship reporting a negative relationship between the two (Matthews, 2003; Adams \& Webley, 2001). Conversely, Engel, Galetovic and Raddatz (2001) declared that tax rate is positively related with sales tax revenue.

Another determinant of tax compliance is threat of penalties in that it has been often deemed to be an efficient preventer of tax non-compliance (Allingham \& Sandmo, 1972). Tax penalty is defined in this study as the imposed sanctions and fines on business that commits sales tax fraud offense. Literature on the topic and empirical findings revealed a positive relationship between tax penalty and enhanced tax compliance (e.g., Yoon, Yoo \& Kim, 2011; Arcand \& Graziosi, 2005; Witte \& Woodbury, 1985). However, some studies in literature revealed no tax compliance-penalties association (e.g., Mohdali, Isa, \& Yusoff, 2014), while others like Also, Feld and Tyran (2002) claimed that penalties do not consequently lead to compliance to payment of tax as the corresponding fine is just symbolic. With regards to the sales tax context, the tax-penalty and sales tax compliance relationship has also been largely ignored. According to some studies dedicated to the relationship examination, including Woodward and Tan (2015) and Webley et al (2004), tax penalties do have a positive relationship with sales tax compliance but others like Faridy et al. (2014) found no significant relationship.

Moving on to the next determinant, which is the tax ethics - the concept of ethic or moral is a complicated one to define and is generally referred to ethics, values or principles that an individual holds (Jackson \& Milliorn, 1986). In relation to this, moral behavior refers to an intrinsic motivation based on moral principles and ethical values (Young, Lei, Wong, \& Kwok, 2016). Therefore, the present study refers to sales tax moral as an intrinsic motivation towards sales tax payment, originating from the ethics compliance to pay sales tax and the strong belief of contributing to the development of the nation. According to Richardson (2006), non-economic factors have the top effect on tax non-compliance compared to economic factors, and moral values were revealed to be one of the top significant factors throughout 45 nations. Hence, taxpayers' moral has to be considered in the examination of tax compliance behavior (Feld \& Schneider, 2010). However, taxpayers who possess tax moral have more likelihood not to be compliant towards paying taxes when they are fiscally stressed or when they perceive that evaders are themselves highly moral and this was reported by Slemrod et al. (2001). Similarly, Fellner, Sausgruber and Traxler (2013) and Ariel (2012) stated that moral persuasion does not necessarily lead to heightened compliance. With regards to the sales tax context, a positive relationship between tax moral and sales tax compliance has been established (Woodward \& Tan, 2015; Adams \& Webley, 2001), but overall, this 
relationship has been under-researched.

Another significant determinant of sales tax compliance is tax fairness (Jackson \& Milliron, 1986). The consensus belief is such that tax administrators and taxpayers are increasingly becoming dissatisfied with the tax system fairness and this causes heightened tax non-compliance rate (Chau \& Leung, 2009). There are two dimensions to tax fairness and they are fairness of commerce and interest received for tax given, and justice of taxpayers' burden in relation to other taxpayers (the understanding of the vertical and horizontal tax laws fairness among taxpayers) (Jackson \& Milliron, 1986). This study refers to tax fairness as the distribution of sales tax registration threshold and sales tax penalties in a fair manner by the tax authority, with fair cost falling on the registered sales tax. A positive relationship was established between tax fairness and tax compliance behavior by some prior studies (e.g., Fochmann \& Kroll, 2015; McKerchar, Bloomquist, \& Pope, 2013; Kirchler \& Wahl, 2010; Feld \& Frey, 2007), others reported no relationship (e.g., Benk, Çakmak \& Budak, 2011), while some others like Sinnasamy, Bidin and Syed-Ismail (2015) reported mixed results. In the sales tax context, literature also showed a positive tax fairness-sales tax compliance association (Woodward \& Tan, 2015; Adams \& Webley, 2001).

In the Fischer Model, peer influence forms an element of the attitudes and perceptions and the term peer refers to the taxpayer's associates that can consist of his/her friends, co-workers, relatives and workmates (Jackson \& Milliron, 1986), and in this study, it is deemed to be another sales tax compliance determinant. Peer influence is defined in this study as the influence of significant people on the business owners when it comes to sales tax compliance decision, contributing to forming their attitudes towards such compliance. A negative relationship between tax compliance and peer influence was reported by some prior studies (e.g., Alon \& Hageman, 2013; Frey \& Torgler, 2007), others supported a positive relationship (e.g., Çevik \& Yeniçeri, 2013; Tusubira \& Nkote, 2013), while some others revealed insignificant relationship between peer influence and tax compliance (Wenzel, 2004; Hite, 1988). In sales tax, studies generally established a positive peer influence-sales tax compliance association (Woodward \& Tan, 2015; Adams \& Webley, 2001).

In sum, the above discussed relationships between tax complexity, tax audit, tax rate, tax penalty, tax ethics, tax fairness and peer influence, and tax compliance in literature had inconsistent findings and such inconsistency calls for further examination. Also, prior studies dedicated to tax compliance determinants largely focused on income tax, while only a few studied sales tax compliance, and majority of them carried out their studies at the individual level rather than business level (e.g., SMEs). The sales tax compliance studies also revealed inconclusive evidence of findings and thus, more studies are needed to establish the relationship. The significance of this finding lies in the fact that majority of the above factors are top tax compliance determinants and they are based on different theoretical underpinnings. To the best of the researcher's knowledge, a study has yet to be conducted to examine the relationship between the above study factors and sales tax compliance among Jordanian SMEs. Therefore, there is the need for more studies to examine this phenomenon, particularly in Jordan The next section is dedicated to presenting the moderating effect of tax services quality.

\subsection{Moderating Effect of Tax Services Quality}

Service quality is defined as the degree to which the service is delivered to best address customer needs in terms of the support of the entity managing the system (DeLone \& McLean, 2003). The issue of service quality is more critical with the new administrative philosophy known as the New Public Management (Brysland \& Curry, 2001). Just like any other public sector organizations, the issue of service quality is also critical to tax offices since they provide numerous services to taxpayers. Tax service quality is a function of brand name and reputation (Hughes \& Moizer, 2015). Conversely, Mustapha and Obid (2014) claimed that tax service quality which includes reliability, responsiveness and in formativeness are important determinants of tax system. In the area of taxation, Jackson and Milliron (1986) almost five decades ago, highlighted the importance of services provided by the Internal Revenue Service (IRS) on US taxpayers. They concluded that the quality of service of tax offices has a significant influence on the behaviour of taxpayers. Tax service quality was also found to influence the efficiency in tax collection which effects the taxpayers' satisfaction and their compliance behavior (Boonyarat, Sofian, \& Wadeecharoen, 2014). Taxpayers' willingness to cooperate with tax authority will increase, if the authority sees itself as service institution and providing quality service and treating the taxpayers as partners (Torgler \& Schneider, 2009). Satisfaction with the government and the tax authority's service also encourages taxpayers to comply with tax rules (Vigoda-Gadot, 2007).

In research Al-Ttaffi and Abdul-Jabbar (2016) mentioned that to improve tax compliance in meeting tax obligations, quality of service tax should be increased by the tax authorities. Good service tax authorities will provide taxpayers, hospitality workers with comfort and facilitate the tax information system, including tax 
services. Alabede and Affrin (2011) found that taxpayers had a low perception of the quality of tax services offered by the tax authority. Their study indicated that there was a positive correlation between perceived tax service quality and tax compliance behaviour. Thus, the improvement in the quality of tax service provided by the tax authority will improve taxpayer's compliance behaviour via better-perceived service quality. Uslaner (2010) argued that poor service quality likely translated into reduced governmental trust, which in turn reduced incentives to comply with tax laws. Thus, tax services quality may play an important role in tax compliance decisions. In a related study, a moderating variable is generally introduced as per the recommendations of Baron and Kenny (1986), whenever the relationship between the two variables is inconsistent. A thorough review of literature on tax compliance showed mixed results among the relationships of tax complexity, tax audit, tax rate, tax penalty, tax moral, tax fairness, peer influence with sales tax compliance. Carnes and Cuccia (1996) found that mixed relations between economic variables and tax compliance that can be explained by a moderating variable. Thus, mix findings may benefit from the examination of tax service quality as a moderating variable. On the basis of the previous discussions, this study proposes the following conceptual framework.

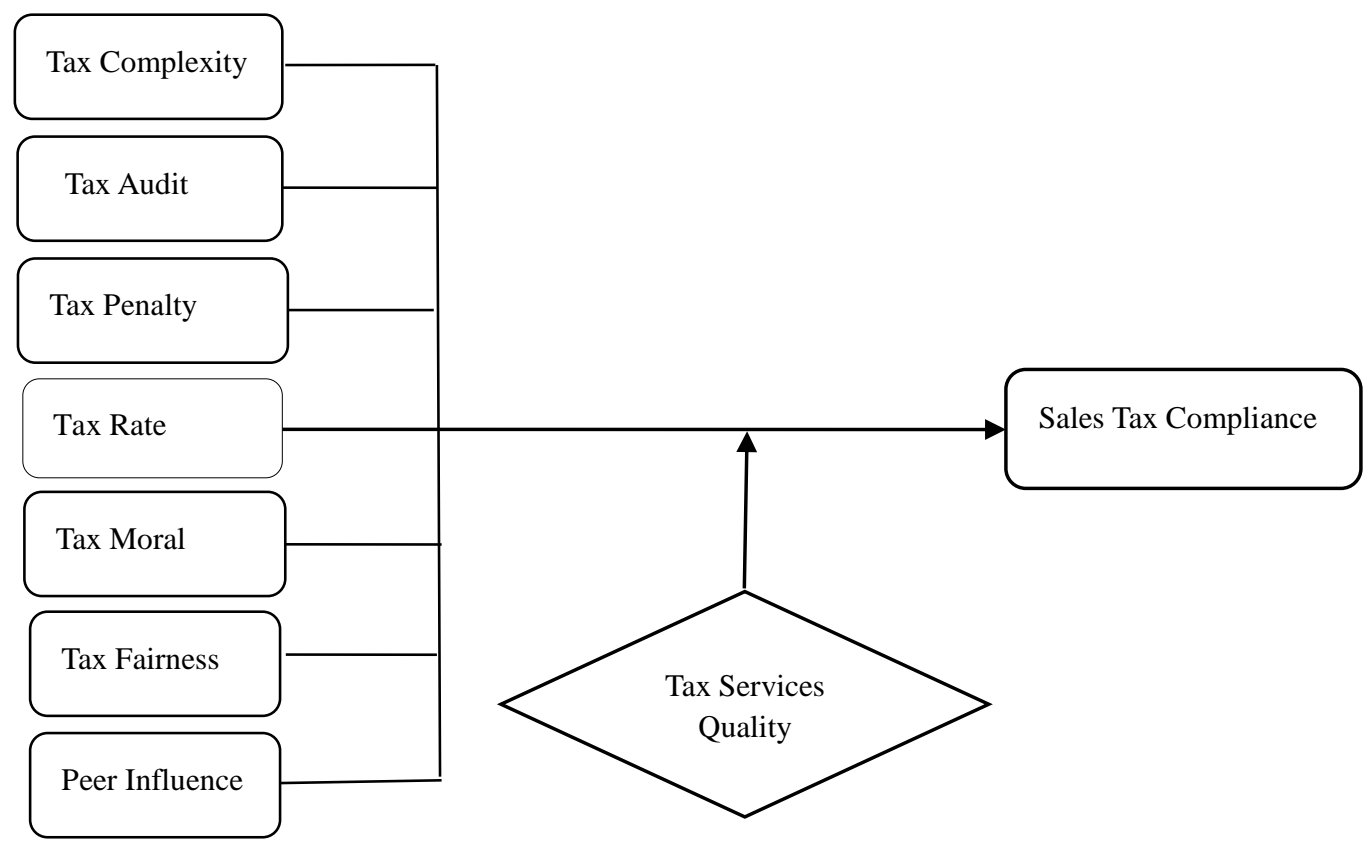

Figure 2. Proposed research framework for sales tax compliance

\section{Method}

The proposed model is a quantitative in nature and is currently part of a larger questionnaire survey undertaken by authors in the Jordanian SMEs context. This research considers 660 SMEs from almost 18,000 registered SMEs in the Jordanian Chamber of Industry (JCI, 2017). The survey questionnaire is built upon prior studies mainly on income tax adapted to suit the Jordanian sales tax compliance environment. The targeted respondents are owner-managers of SMEs as they have reasonable knowledge about their businesses and has an appropriate capacity in their respective businesses.

\section{Data Analysis}

Once the collection of data is done, data analysis is required to convert the raw data into information (Zikmund et al., 2013). Firstly, descriptive statistics will be employed, such as mean and standard deviations, and frequencies to describe the socio-economic variables (nominally scaled) of the respondents (Sekaran, 2003). Then, the study will use a well-known multivariate technique called Structural Equation Modeling (SEM).Vogt and Johnson (2015, p. 431) stated that SEM is "an equation representing the strength and nature of the hypothesized relations among the 'structure' of sets of variables in a theory". Guo, Perron, and Gillespie (2008) proposed that SEM has played a significant role in the knowledge development for social work. Additionally, Cheng (2001) revealed that SEM favored statistical technique among social science researchers and has been found to be better than other multivariate techniques including multiple regression analysis for examining a series of dependent relationships simultaneously. 
The current study will use PLS-SEM because of the complexity of the models to be employed in this study, which is in keeping with the recommendation of Hair et al. (2010), as well as the small sample size, no assumptions about data distribution, friendly user, freely available to researchers and academics (Wong, 2013; Hwang, Malhotra, Kim, Tomiuk, \& Hong, 2010; Esposito-Vinzi, Trinchera, Squillacciotti, \& Tenenhaus, 2008).

\section{Implications}

The present study would make significant contributions to various stakeholders in relation to issues of tax compliance in the economy including the governments, tax authorities, policy makers, particularly in the Arab countries and Middle East. The study would also enhance the understanding and knowledge of sales tax compliance and provide useful information to tax authorities regarding the effect of the socio-psychological factors as well as deterrence elements on sales tax compliance behavior. Thus, it would add more literature on sales tax compliance among the SMEs, particularly in Jordan and the world at large. The current study probably the first to examine the sales tax compliance of SMEs in the Middle East and Arab countries and is the first in the context of Jordan. The present study also would provide necessary information that will be beneficial for formulating suitable policies to combat tax non-compliance which will help to avoid distorted decisions, and then increases tax revenue to Jordanian government especially at this time where increased public debt and deficit of fiscal budget becomes issues of concern.

\section{Conclusion}

In the Jordanian case, sales tax is considered to be a major government revenue source and basically, this forms a part of the implementation of government policies that are directed towards meeting the country's development. However, tax non-compliance has resulted in government budget deficits and this influences the country's growth and development. The fight against sales tax non-compliance and in effect, boosting sales tax compliance is a typical government plan aimed towards increasing tax revenues and government competence. More importantly, several scholars from the many economic disciplines have addressed the tax compliance topic. In the present research, a model is proposed to provide insight into the sales tax compliance of Jordanian SMEs. The model is an extension of the Fischer model, with the consideration of the moderating role of tax service quality on the relationships of socio-psychological factors (tax moral, peer influence, tax fairness), economic factors (tax complexity, tax audit, tax rate and tax penalty) with sales tax compliance. The proposed framework has several critical implications forunderstanding and unveiling the determinants that may influence the sales tax compliance of SMEs. These will be useful to all. Particulary, if the proposed model is validated, the research in the future will adopt a positivist method in the process of data collection and the results will provide significant insight to academicians, policy makers, tax authority, practitioners and other regulatory authorities in policy evaluation and formulations to be used for understanding the relevant determinants of sales tax compliance of SMEs. Moreover, the results will have practical implications towards achieving the Jordanian vision 2025 and beyond. Other additional factors may also be examined by future studies such as, government subsidy removal and sales tax compliance cost, in the SMEs sales tax compliance case.

\section{References}

Abdixhiku, L., Krasniqi, B., Pugh, G., \& Hashi, I. (2017). Firm-level determinants of tax evasion in transition economies. Economic Systems, 41(3), 354-366. https://doi.org/10.1016/j.ecosys.2016.12.004

Abdixhiku, L., Pugh, G., \& Hashi, I. (2018). Business tax evasion in transition economies: a cross-country panel investigation. The European Journal of Comparative Economics, 15(1), 11-36. https://doi.org/10.25428/1824-2979/201801-11-36

Abdul-Jabbar, H., \& Pope, J. (2008). Exploring the relationship between tax compliance costs and compliance issues in Malaysia. Journal of Applied Law and Policy, 1(1), 1-20.

Abdul-Jabbar, H., \& Pope, J. (2008). The effects of the self-assessment system on the tax compliance costs of small and medium enterprises in Malaysia. Journals in Business \& Management, 23, 289-307.

Adams, C., \& Webley, P. (2001). Small business owners' attitudes on VAT compliance in the UK. Journal of Economic Psychology, 22(1), 195-21. https://doi.org/10.1016/S0167-4870(01)00029-0

Alabede, J. O., \& Zainal Affrin, Z. (2011). Tax service quality and compliance behaviour in Nigeria: Do taxpayer's financial condition and risk preference play any moderating role?. European Journal of Economics, Finance and Administrative Sciences, 35, 90-108 http://repo.uum.edu.my/id/eprint/3854

Al-Bakri, A., Matar, M., \& Nour, A. N. (2014). The required information and financial statements disclosure in SMEs. Journal of Finance and Accountancy, 16(9), 1-15. 
Ali, M. M., Cecil, H. W., \& Knoblett, J. A. (2001). The effects of tax rates and enforcement policies on taxpayer compliance: A study of self-employed taxpayers. Atlantic economic journal, 29(2), 186-202. https://doi.org/10.1007/BF02299137

Allingham, M., \& Sandmo, A. (1972). Income tax evasion: A theoretical analysis. Journal of Public Economics, l(3-4), 323-338. https://doi.org/10.1016/0047-2727(72)90010-2

Alm, J. (1991). A perspective on the experimental analysis of taxpayer reporting. The Accounting Review, 66(3), 577-593.

Alm, J. (1999). Tax Compliance and Administration. In W. B. Hildreth and J. A. Richardson (Eds.), Handbook on Taxation (pp. 741-768). Marcel Dekker, New York.

Alm, J. (2012). Measuring, explaining, and controlling tax evasion: lessons from theory, experiments, and field studies. International Tax and Public Finance, 19(1), 54-77. https://doi.org/10.1007/s10797-011-9171-2

Alm, J., \& El-Ganainy, A. (2013). Value-added taxation and consumption. International Tax and Public Finance, 20(1), 105-128. https://doi.org/10.1007/s10797-012-9217-0

Alm, J., \& McClellan, C. (2012). Tax morale and tax compliance from the firm's perspective. Kyklos, 65(1), 1-17. https://doi.org/10.1111/j.1467-6435.2011.00524.x

Alm, J., \& Mckee, M. (2006). Audit certainty, audit productivity, and taxpayer compliance. Andrew Young School of Policy Studies Research, 59(4), 06-43.

Alm, J., \& Torgler, B. (2011). Do ethics matter? tax compliance and morality. Journal of Business Ethics, 101(4), 635-651. https://doi.org/10.1007/s10551-011-0761-9

Alm, J., Clark, J., \& Leibel, K. (2016). Enforcement, socioeconomic diversity, and tax filing compliance in the United States. Southern Economic Journal, 82(3), 725-747. https://doi.org/10.1002/soej.12106

Alm, J., Jackson, B. R., \& McKee, M. (1993). Fiscal exchange, collective decision institutions, and tax compliance. Journal of Economic Behavior \& Organization, 22(3), 285-303. https://doi.org/10.1016/0167-2681(93)90003-8

Alm, J., Jackson, B., \& McKee, M. (1992). Estimating the determinants of taxpayer compliance with experimental data. National Tax Journal, 45(1), 107-114.

Alm, J., Sanchez, I., \& De-Juan, A. (1995). Economic and noneconomic factors in tax compliance. KYKLOS, 48(1), 1-18. https://doi.org/10.1111/j.1467-6435.1995.tb02312.x

Alon, A., \& Hageman, A. M. (2013). The impact of corruption on firm tax compliance in transition economies: Whom do you trust? Journal of Business Ethics, 116(3), 479-494. https://doi.org/10.1007/s10551-012-1457-5

Alrousan, M. K., \& Jones, E. (2016). A conceptual model of factors affecting e-commerce adoption by SME owner / managers in Jordan. International Journal of Business Information Systems, 21(3), 269-308. https://doi.org/10.1504/IJBIS.2016.074762

AL-Shawawreh, T. B., \& AL-Smirat, B. Y. (2016). Economic effects of tax evasion on Jordanian economy. International Journal of Economics and Finance, 8(7), 344-348. https://doi.org/10.5539/ijef.v8n7p344

Alshir'ah, A. F., Abdul-Jabbar, H., \& Samsudin, R. S. (2016). Determinants of sales tax compliance in small and medium enterprises in Jordan: A call for empirical research. World Journal of Management and Behavioral Studies, 4(1), 41-46. https://doi.org/10.5829/idosi.wjmbs.2016.4.1.1327

Alshira'h, A. F., Abdul-Jabbar, H., \& Samsudin, R. S. (2018). Sales tax compliance model for the Jordanian Small and medium enterprises research. Journal of Advanced Research in Social and Behavioural Sciences, 10(2), 115-130.

Al-Smirat, B. Y. (2013). The use of accounting information by small and medium enterprises in South District of Jordan (An empirical study). Research Journal of Finance and Accounting, 4(6), 169-175.

Al-Ttaffi, L, \& Abdul-Jabbar, H. (2016). Service quality and income tax non-compliance among small and medium enterprises in Yemen. Journal of Advanced Research in Business and Management Studies, 4(1), 12-21.

Al-Zoubi, A., Khatatba, H., Salama, R. B., \& Khatataba, M. (2013). Methods of tax avoidance and evasion: The incapability of the Jordanian income tax law to face tax avoidance and evasion. Journal Almanara, 19(4), 9-36. 
Andreas, \& Savitri, E. (2015). The effect of tax socialization, tax knowledge, expediency of tax id number and service quality on taxpayers compliance with taxpayers awareness as mediating variables. Procedia - Social and Behavioral Sciences, 211(9), 163-169. https://doi.org/10.1016/j.sbspro.2015.11.024

Andreoni, J., Erard, B., \& Feinstein, J. (1998). Tax compliance. Journal of Economic Literature, 36(2), 818-860.

Arcand, J. L., \& Graziosi, G. R. (2005). Tax compliance and rank dependent expected utility. The Geneva Risk and Insurance Review, 30(1), 57-69. https://doi.org/10.1007/s10836-005-1108-1

Ariel, B. (2012). Deterrence and moral persuasion effects on corporate tax compliance: Findings from a randomized controlled trial. Criminology, 50(1), 27-69. https://doi.org/10.1111/j.1745-9125.2011.00256.x.

Association of Banks in Jordan. (2016). Small and medium enterprises in Jordan, analysis of supplies-side and demand-side focusing on banking financing. Studies Department. Retrieved from http://www.abj.org.jo/ar-jo/otherstudies.aspx

Azmi, A., Sapiei, N. S., Mustapha, M. Z., \& Abdullah, M. (2016). SMEs' tax compliance costs and IT adoption: The case of a value-added tax. International Journal of Accounting Information Systems, 23, 1-13. https://doi.org/10.1016/j.accinf.2016.06.001

Baron, R. M., \& Kenny, D. A. (1986). The moderator-mediator variable distinction in social psychological research: Conceptual, strategic, and statistical considerations. Journal of Ppersonality and Ssocial Ppsychology, 51(6), 1173. https://doi.org/10.1037/0022-3514.51.6.1173

Becker, G. S. (1968). Crime and punishment: An economic approach. The Journal of Political Economy, 76(2), 169-217. https://doi.org/10.1086/259394

Benk, S., Cakmak, A. F., \& Budak, T. (2011). An investigation of tax compliance intention: A theory of planned behavior approach. European Journal of Economics, Finance and Administrative Sciences, 28, 180-188.

Bird, R. M., \& Martinez-Vazquez, J. \& Torgler, B. (2008). Tax effort in developing countries and high income countries: The impact of corruption, voice and accountability. Economic Analysis and Policy, 38(1), 55-71. https://doi.org/10.1016/S0313-5926(08)50006-3

Boonyarat, N., Sofian, S., \& Wadeecharoen, W. (2015). The antecedents of taxpayers' compliance behavior and the effectiveness of Thai local government levied tax. International Business Management, 9(2), 182-190.

Brown, R., \& Mazur, M. (2003). IRS' s comprehensive approach to compliance measurement. National Tax Journal, 56(3), 689-700. https://doi.org/10.17310/ntj.2003.3.15

Brysland, A., \& Curry, A. (2001). Service improvements in public services using SERVQUAL. Managing Service Quality: An International Journal, 11(6), 389-401. https://doi.org/10.1108/09604520110410601

Çevik, S., \& Yeniçeri, H. (2013). The relationship between social norms and tax compliance: The moderating role of the effectiveness of tax administration. International Journal of Economic Sciences, 2(3), 166-180.

Chan, C. W., Troutman, C. S., \& Bryan, D. (2000). An expanded model of taxpayer compliance: Empirical evidence from the United States and Hong Kong. Journal of International Accounting, Auditing and Taxation, 9(2), 83-103. https://doi.org/10.1016/S1061-9518(00)00027-6

Chau, G., \& Leung, P. (2009). A critical review of Fischer tax compliance model: A research synthesis. Journal of Accounting and Taxation, 1(2), 34-40.

Crocker, K. J., \& Slemrod, J. (2005). Corporate tax evasion with agency costs. Journal of Public Economics, 89(9-10), 1593-1610. https://doi.org/10.1016/j.jpubeco.2004.08.003

Cuccia, A. D., \& Carnes, G. A. (2001). A closer look at the relation between tax complexity and tax equity

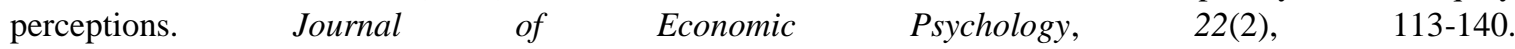
https://doi.org/10.1016/S0167-4870(01)00025-3

Das-Gupta, A., \& Gang, I. (2003). Value added tax evasion, auditing and transactions matching. In 1. Maclarn (Ed.), Institutional elements of tax design and reform (pp. 25-48). The World Bank, Washington, USA.

Delone, W. H., \& McLean, E. R. (2003). The DeLone and McLean model of information systems success: A ten-year update. Journal of Management Information Systems, 19(4), 9-30. https://doi.org/10.1080/07421222.2003.11045748

Devos, K. (2008). Tax evasion behaviour and demographic factors: An exploratory study in Australia. Revenue Law Journal, 18(1), 1-45. 
Engel, E. M., Galetovic, A., \& Raddatz, C. E. (2001). A note on enforcement spending and VAT revenues. Review of Economics and Statistics, 83(2), 384-387. https://doi.org/10.1162/rest.2001.83.2.384

Faridy, N., Copp, R., Freudenberg, B., \& Sarker, T. (2014). Complexity, compliance costs and non compliance with VAT by small and medium enterprises in Bangladesh: Is there a relationship. Australian Tax Forum, 29, 281-329. https://doi.org/10.2139/ssrn.2479146

Faridy, N., Freudenberg, B., Sarker, T., \& Copp, R. (2016). The hidden compliance cost of VAT: An exploration of psychological and corruption costs of VAT in a developing country. eJournal of Tax Research, 14(1), 166-205.

Fauvelle-Aymar, C. (1999). The political and tax capacity of government in developing countries. Kyklos, 52(3), 391-413. https://doi.org/10.1111/j.1467-6435.1999.tb00224.x

Feinstein, J. S. (1991). An econometric analysis of income tax evasion and its detection. The RAND Journal of Economics, 22(1), 14-35. https://doi.org/10.2307/2601005

Feld, L. P., \& Larsen, C. (2012). Self-perceptions, government policies and tax compliance in Germany. International Tax and Public Finance, 19(1), 78-103. https://doi.org/10.2307/2601005

Feld, L. P., \& Schneider, F. (2010). Survey on the Shadow Economy and Undeclared Earnings in OECD Countries. German Economic Review, 11(2), 109-149. https://doi.org/10.1111/j.1468-0475.2010.00509.x

Feld, L. P., \& Tyran, J. R. (2002). Tax evasion and voting: An experimental analysis. Kyklos, 55(2), 197-221. https://doi.org/10.1111/1467-6435.00183

Feld, L. P., Frey, B. S., \& Torgler, B. (2006). Rewarding honest taypayers? Evidence on the impact of rewards from field exeperiments (Working paper). Center for Research in Economics, Management and the Arts.

Feld, L., \& Frey, B. (2007). Tax compliance as the result of a psychological tax contract: The role of incentives and responsive regulation. Law and Policy, 29(1), 102-120. https://doi.org/10.1111/j.1467-9930.2007.00248.x

Fellner, G., Sausgruber, R., \& Traxler, C. (2013). Testing enforcement strategies in the field: Threat, moral appeal and social information. Journal of the European Economic Association, 11(3), 634-660. https://doi.org/10.1111/jeea.12013

Fischer, C.M., Wartick, M., \& Mark, M. (1992). Detection probability and taxpayer compliance: A review of the literature. Journal of Accounting Literature, 11(2), 1-25.

Fochmann, M., \& Kroll, E. (2015). The effects of rewards on tax compliance decisions. Journal of Economic Psychology, 52, 38-55. https://doi.org/10.1016/j.joep.2015.09.009

Franzoni, L. A. (1999). Tax evasion and tax compliance. In B. Bouckaert, \& G. De Geest (Eds.). Encyclopedia of Law and Economics (pp. 52-94). Cheltenham, UK: Edward Elgar.

Frey, B. (2003). Deterrence and tax morale in the European Union. European Review, 11(3), 385-406. https://doi.org/10.1017/S1062798703000346.

Frey, B., \& Torgler, B. (2007). Tax morale and conditional cooperation. Journal of Comparative Economics, 35(1), 136-159. https://doi.org/10.1016/j.jce.2006.10.006.

Giesecke, J., \& Tran, N. H. (2012). A general framework for measuring VAT compliance rates. Applied Economics, 44(15), 1867-1889. https://doi.org/10.1080/00036846.2011.554382

Hanefah, H. (1996). An evaluation of the malaysian tax administrative system and tax payers' perceptions towards assessment systems, tax law fairness, and tax law complexity (Unpublished doctoral thesis, Universiti Utara Malaysia)

Hansford, A., \& Hasseldine, J. (2012). Tax compliance costs for small and medium sized enterprises: The case of the UK. eJournal of Tax Research, 10(2), 288-303.

Hite, P. A. (1988). The effect of peer reporting behavior on taxpayer compliance. Journal of the American Taxation Association, 9(2), 47-64.

Hughes, J., \& Moizer, P. (2015). Assessing the quality of services provided by UK tax practitioners. eJournal of Tax Research, 13(1).

Income and Sales Tax Department. (2016). Anual report. Retrieved from http://www.istd.gov.jo/AttachedArabic/projectplan/202016\%الكتاب\%20\%.pdf 
Jackson, B. R., \& Milliron, C. V. (1986). Tax compliance research: Findings, problems and prospects. Journal of Accounting Literature, 5, 125-165.

Jordan Independent Economic Watch. (2014). Tax burden in Jordan, reality \& prospects. Retrieved from http://www.identity-center.org

Jordanian Chamber of Industry. (2017). Industry Director. Retrieved from http://www.jci.org.jo

Joulfaian, D. (2000). Corporate income tax evasion and managerial preferences. Review of Economics and Statistics, 82(4), 698-701. https://doi.org/10.1162/rest.2000.82.4.698.

Joulfaian, D. (2009). Bribes and business tax evasion. European Journal of Comparative Economics, 6(2), $227-244$.

Kasipillai, J., \& Abdul-Jabbar, H. (2006). Gender and ethnicity differences in tax compliance. Asian Academy of Management Journal, 11(2), 73-88.

Kim, S. (2008). Does political intention affect tax evasion?. Journal of Policy Modeling, 30(3), 401-415. https://doi.org/10.1016/j.jpolmod.2007.12.004

Kirchler, E., \& Wahl, I. (2010). Tax compliance inventory TAX-I: Designing an inventory for surveys of tax compliance. Journal of Economic Psychology, 31(3), 331-346. https://doi.org/10.1016/j.joep.2010.01.002

Kirchler, E., Kogler, C., \& Muehlbacher, S. (2014). Cooperative tax compliance: From deterrence to deference. Current Directions in Psychological Science, 23(2), 87-92. https://doi.org/10.1177/0963721413516975

Kirchler, E., Muehlbacher, S., Kastlunger, S., \& Wahl, I. (2007). Why pay taxes? A review of tax compliance decisions (Working Paper). International Studies Program, Georgia State University.

Kirchler, E., Niemirowski, A., \& Wearing, A. (2006). Shared subjective views, intent to cooperate and tax compliance: Similarities between Australian taxpayers and tax officers. Journal of Economic Psychology, 27(4), 502-517. https://doi.org/10.1016/j.joep.2006.01.005

Lee, D., Kim, D., \& Borcherding, T. E. (2013). Tax structure and government spending: does the value-added tax increase the size of government?. National Tax Journal, 66(3), 541-570. https://doi.org/10.17310/ntj.2013.3.02

Lutfi, A. A., Idris, K., \& Mohamad, R. (2017). AIS usage factors and impact among Jordanian SMEs: The moderating effect of environmental uncertainty. Journal of Advanced Research in Business and Management Studies, 6(1), 24-38.

Matthews, K. (2003). VAT evasion and VAT avoidance: Is there a European laffer curve for VAT? International Review of Applied Economics, 17(1), 37-41. https://doi.org/10.1080/713673162

Matthews, S. K., \& Agnew, R. (2008). Extending deterrence theory: Do delinquent peers condition the relationship between perceptions of getting caught and offending?. Journal of Research in Crime and Delinquency, 45(2), 91-118. https://doi.org/10.1177/0022427807313702

McKerchar, M., Bloomquist, K., \& Pope, J. (2013). Indicators of tax morale: An exploratory study. eJournal of Tax Research, 11(1), 5-22.

Ministry of Finance (2016). General government financial statements. General Government Bulletins for December. Retrieved from http://www.mof.gov. jo

Mohdali, R., Isa, K., \& Yusoff, S. H. (2014). The impact of threat of punishment on tax compliance and non-compliance attitudes in Malaysia. Procedia - Social and Behavioral Sciences, 164, 291-297. https://doi.org/10.1016/j.sbspro.2014.11.079

Morse, S. C., Karlinsky, S., \& Bankman, J. (2009). Cash businesses and tax evasion. Stanford Law and Policy Review, 20(1), 1-67.

Muche, B. (2014). Determinants of tax payer's voluntary compliance with taxation in east Gojjam-Ethiopia. Research Journal of Economics \& Businrss Studies, 3(9), 41-50.

Mustapha, B., \& Obid, S. N. B. S. (2015). Tax service quality: The mediating effect of perceived ease of use of the online tax system. Procedia-Social and Behavioral Sciences, 172, 2-9. https://doi.org/10.1016/j.sbspro.2015.01.328

Nura, M., Abdul-Jabbar, H., \& Ibrahim, I. (2017). VAT compliance and the influence of political and business environment: A proposed framework for Nigerian SMEs. Asian Journal of Business Management Studies, 
$8(2), 13-20$.

Nur-tegin, K. D. (2008). Determinants of business tax compliance. The BE Journal of Economic Analysis \& Policy, 8(1).1-28. https://doi.org/10.2202/1935-1682.1683

Palil, M. R., Zain, N. H. M., \& Faizal, S. M. (2012). Political affiliation and tax compliance in Malaysia. Humanities and Social Sciences Review, 1(4), 395-402.

Pellizzari, P., \& Rizzi, D. (2014). Citizenship and power in an agent-based model of tax compliance with public expenditure. Journal of Economic Psychology, 40, 35-48. https://doi.org/10.1016/j.joep.2012.12.006

Pommerehne, W. W., \& Weck-Hannemann, H. (1996). Tax rates, tax administration and income tax evasion in Switzerland. Public Choice, 88(1/2), 161-170. https://doi.org/10.1007/BF00130416

Pope, J., \& Abdul-Jabbar, H. (2008). Small and medium-sized enterprises and tax compliance burden in Malaysia: Issues and challenges for tax administration. Small Enterprise Research, 16(1), 47-60. https://doi.org/10.5172/ser.16.1.47

Randlane, K. (2016). Tax Compliance as a system: Mapping the field. International Journal of Public Administration, 39(7), 515-525. https://doi.org/10.1080/01900692.2015.1028636

Richardson, G. (2006). Determinants of tax evasion: A cross-country investigation. Journal of International Accounting, Auditing and Taxation, 15(2), 150-169. https://doi.org/10.1016/j.intaccaudtax.2006.08.005

Ritsatos, T. (2014). Tax evasion and compliance: From the neo classical paradigm to behavioural economics, a review. Journal of Accounting \& Organizational Change, 10(2), 244-262. https://doi.org/10.1108/JAOC-07-2012-0059

Roth, J. A., \& Scholz, J. T. (1989). Taxpayer Compliance, Volume 1: An Agenda for Research (Vol. 1). University of Pennsylvania Press. https://doi.org/10.9783/9781512806274

Samuel, M., \& Dieu, R. (2014). The impact of taxpayers' financial statements audit on tax revenue growth. International Journal of Business and Economic Development, 2(2), 51-60.

Sawyer, A. (2014). Comparing the Swiss and United Kingdom cooperation agreements with their respective agreements under the Foreign account tax compliance act. eJournal of Tax Research, 12(2), 285-318.

Saymeh, A. A. F., \& Sabha, S. A. (2014). Assessment of Small Enterprise Financing ,case of Jordan. Global Journal of Management and Business Research, 14(2), 6-18.

Seren, M. J., \& Panades, J. (2013). Do higher tax rates encourage / discourage tax compliance ? Modern Economy, 4(12), 809-817. https://doi.org/10.4236/me.2013.412086

Sinnasamy, P., Bidin, Z., \& Syed-Ismail, S. S. (2015). A proposed model of non-compliance behaviour on excise duty: A moderating effects of tax agents. Procedia - Social and Behavioral Sciences, 2011, 299-305. https://doi.org/10.1016/j.sbspro.2015.11.038

Slemrod, J. (2007). Cheating ourselves: The economics of tax evasion. The Journal of Economic Perspectives, 21(1), 25-48. https://doi.org/10.1257/jep.21.1.25

Slemrod, J., Blumenthal, M., \& Christian, C. (2001). Taxpayer response to an increased probability of audit: Results from a controlledexperiement in Minnesota. Journal of Public Economics, 79, 455-483. https://doi.org/10.1016/S0047-2727(99)00107-3

Tehulu, T. A., \& Dinberu, Y. D. (2014). Determinants of tax compliance behavior in Ethiopia: The case of bahir dar city taxpayers. Journal of Economics and Sustainable Development, 5(15), 268-274.

Torgler, B. (2007). Tax compliance and tax morale: A theoretical and empirical analysis (pp. 1-317). Edward Elgar Publishing. UK. https://doi.org/10.4337/9781847207203

Torgler, B., \& Schneider, F. (2009). The impact of tax morale and institutional quality on the shadow economy. Journal of Economic Psychology, 30(2), 228-245. https://doi.org/10.1016/j.joep.2008.08.004.

Tusubira, F. N., \& Nkote, I. N. (2013). Social Norms, taxpayers' morale and tax compliance: The case of small business enterprises in Uganda. Journal of Accounting, Taxation and Performance Evaluation, 2(1), 1-10.

Uslaner, E. M. (2010). Tax evasion, corruption, and the social contract in transition. Developing Alternative Frameworks for Explaining Tax Compliance, 59, 174.0-108.

Vadde, S. (2014). Compliance and non compliance behavior of business profit taxpayers' towards the tax system: A case study of Mekelle city. Scholars Journal of Economics, Business and Management, 1(10), 525-531. 
http://dx.doi.org/10.18034/abcra.v5i1.973

Varvarigos, D. (2016). Cultural norms, the persistence of tax evasion, and economic growth. Economic Theory, 21(5), 1-35. https://doi.org/10.1007/s00199-016-0976-1

Vigoda-Gadot, E. (2006). Citizens' perceptions of politics and ethics in public administration: A five-year national study of their relationship to satisfaction with services, trust in governance, and voice orientations. Journal of Public Administration Research and Theory, 17(2), 285-305. https://doi.org/10.1093/jopart/muj018

Wenzel, M. (2004). An analysis of norm processes in tax compliance. Journal of Economic Psychology, 25(2), 213-228. https://doi.org/10.1016/S0167-4870(02)00168-X

Witte, A. D., \& Woodbury, D. F. (1985). The effect of tax laws and tax administration on tax compliance: The case of the US individual income tax. National Tax Journal, 38(1), 1-13.

Woodward, L., \& Tan, L. M. (2015). Small business owners attitudes toward GST compliance : A preliminary study. Australian Tax Forum, 30(2), 517-550. https://doi.org/10.2139/ssrn.2666317

Yitzhaki, S. (1974). Income tax evasion: A theoretical analysis. Journal of public economics, 3(2), 201-202. https://doi.org/10.1016/0047-2727(74)90037-1

Yoon, S. S., Yoo, S. W., \& Kim, J. (2011). Ambiguity, audit errors, and tax compliance. Asia-Pacific Journal of Accounting \& Economics, 18(1), 11-26. https://doi.org/10.1080/16081625.2011.9720871

Young Entrepreneure Association. (2011). Small and medium business agenda. Retrieved from http://www.cipe-Arabia.org

Young, A., Lei, L., Wong, B., \& Kwok, B. (2016). Individual tax compliance in China: A review. International Journal of Law and Management, 58(5), 1-12. https://doi.org/10.1108/IJLMA-12-2015-0063

\section{Copyrights}

Copyright for this article is retained by the author(s), with first publication rights granted to the journal.

This is an open-access article distributed under the terms and conditions of the Creative Commons Attribution license (http://creativecommons.org/licenses/by/4.0/). 